\title{
Anger Expression, Depression, Anxiety and Stress among Turkish Students Living in Turkey and Germany
}

\author{
Nuran Bayram, Ph.D \\ Professor, Uludag University, Faculty of Economics and Administrative Sciences, Department \\ of Econometrics 16059 Bursa /TURKEY \\ E-mail: nuranb@uludag.edu.tr
}

\begin{abstract}
Atilla Dogan
Assistant Professor, Anadolu University, Open Education Faculty, Eskişehir/ TURKEY

E-mail: aadogan@anadolu.edu.tr
\end{abstract}

Ismail Aydogan

Associate Professor, Erciyes University, Faculty of Education Kayseri /TURKEY

E-mail: aydogani@erciyes.edu.tr

Nazan Bilgel, M.D.

Professor (corresponding author), Uludag University, Faculty of Medicine, Department of Family Medicine 16059 Bursa/ TURKEY

E-mail: nazan@uludag.edu.tr

DOI: $\quad 10.6007 /$ IJARBSS/v4-i3/669 URL: http://dx.doi.org/10.6007/IJARBSS/v4-i3/669

\begin{abstract}
In the present cross-sectional, descriptive study, different dimensions of anger and symptoms of depression, anxiety and stress were evaluated in a group of Turkish students in grades 9-12 who were living in Turkey $(\mathrm{N}=442)$ and Germany $(\mathrm{N}=320)$. Depression-Anxiety and Stress Scale-42 (DASS-42) and Multi Dimensional Anger Scale (MDAS) were used. Students living in Turkey had higher scores of anxiety and stress than those living in Germany. Scores of anger symptoms were found to be higher among students in Turkey. Being belittled, transgressed against and criticized were found to be important anger eliciting situations. Among students in Germany, aggressive and revengeful reactions were higher among males than females whereas in Turkey no gender differences were found. Passive-aggressive reactions were higher among female students in Turkey whereas in Germany no gender differences were found. All of the scores for the subscales of MDAS increased with the increasing grades of the students.
\end{abstract}

Keywords: Depression; anxiety; stress; anger; Turkish students.

JEL Classification: I19 Other 


\section{Introduction}

Anger is an emotional state typically accompanied by psychological and biological changes, and it can vary from minor annoyance to rage (APA, 2007). There are many definitions of anger in the literature. Kassinove \& Sukhodolsky (1995) defined anger as a negative, phenomenological or internal feeling state. According to Lewis (1993) and Golden (2003), anger is a basic emotion and a response to distress related to environmental obstacles whose function is to provide the organism with motivated capacities to overcome those obstacles. Novaco (1975) defined anger as having four distinct components: physiological, affective, behavioral and cognitive. Spielberger (1999) identified two aspects of anger: (a) state anger, in which the individual responds emotionally to circumstances and (b) trait anger, which is a more pervasive response.

Modern psychologists view anger as a primary, natural, and mature emotion experienced by all humans, and as something that has functional value for survival. Parker-Hall (2008), for instance, conceptualizes controlled anger as a positive, pure and constructive emotion that is always respectful of others, something that is only ever utilized to protect the self physically, emotionally, intellectually and spiritually in relationships. On the other hand, uncontrolled anger can be a significant problem and can result in depression, suicidal tendencies, substance abuse, hostility, rage, violence and crime. Some studies have revealed associations between depression, anxiety, stress and anger expression (Thomas \& Atakan, 1993; Sperberg \& Stabb, 1998; Verschuur, Eurelings- Bontekoe \& Spinhoven, 2004; Koh, Kim, Kim \& Park, 2005; Goodwin, 2006; Kitamura \& Hasui, 2006). Goodwin (2006) analyzed data from a health behavior survey of US school-aged children and noted that outward anger expression was associated with an almost threefold increase in the risk of feelings of depression among boys. Similarly Orpinas, Basen-Engquist, Grunbaum \& Parcel (1995) noted that students exhibiting violent behaviors in schools were more likely to have symptoms of depression than students not exhibiting such behaviors. Moreover, positive associations between anger expression and symptoms of depression have been reported in both American and Turkish women (Thomas \& Atakan, 1993).

Although scarce, available data from studies conducted in Turkey suggest a high frequency of outward anger expression among high school students (Batıgün-Durak \& Şahin-Hisli, 2003; Batıgün-Durak \& Utku, 2006; Çivitçi, 2007; Köksal \& Gençdoğan, 2007; Şahin-Hisli \& Batıgün- Durak, 2009). Studies have also revealed high frequencies of depression, anxiety and stress among students (Ceylan, Özen, Palancl, 2003; Eskin, Ertekin, Harlak \& Dereboy, 2008). To date, few studies have evaluated the associations between anger and symptoms of depression, anxiety and stress among Turkish youth. In this study, therefore, we sought to evaluate anger expression and symptoms of depression, anxiety and stress among Turkish youth who were living in Turkey and in Germany.

\section{Material and Methods}

\subsection{Research Design}

This study is a cross-sectional, descriptive study which relies on self-reporting. Data was collected anonymously, and students participated voluntarily. Both the students and their parents were informed about the study, and those who did not want to participate were excluded.

\subsection{Study Participants}

Our study group consisted of 762 Turkish students from grades 9-12. Three hundred twenty students were selected from two high schools in Germany in areas settled largely by Turkish 
immigrants, and 442 students were selected from two high schools in Turkey. All of the students in Germany had Turkish nationality, were born in Germany and could speak both Turkish and German.

\subsection{Study Instruments}

In this study we used two instruments: the Multidimensional Anger Scale and the Depression-Anxiety and Stress Scale-42.

The Multidimensional Anger Scale (MDAS), developed by Balkaya \& Şahin-Hisli (2003), is a five point Likert-type, self-report scale where $1=$ Never and $5=$ Always. This instrument measures one's anger in terms of five dimensions: bodily symptoms, anger-related situations, anger-related cognitions, anger-related behaviors and interpersonal anger. Except for the bodily symptoms, each dimension is composed of several factor-based subscales. The anger-related situations dimension has 42 items which are clustered into 3 subscales: being transgressed against ( 17 items), being criticized ( 5 items) and being belittled ( 20 items). The anger-related cognition dimension has 30 items which are clustered into 4 subscales: regarding anger (9 items), regarding others ( 9 items), regarding him or herself ( 7 items) and regarding the whole world ( 5 items). The anger-related behaviors dimension has 26 items, clustered into 3 subscales: aggressive behaviors (12 items), calm behaviors (10 items) and anxious behaviors (4 items). Finally, the interpersonal anger dimension has 47 items which are clustered into 4 subscales: being revengeful ( 24 items), passive-aggressive reactions (10 items), inwards directed reactions (10 items) and being indifferent (3 items). According to Balkaya \& Şahin-Hisli's (2003) psychometric analysis, the scale possesses adequate internal consistency (alpha coefficients between 0.64 and 0.95).

The Depression-Anxiety and Stress Scale-42 (DASS-42) scale was developed by Lovibond \& Lovibond (PFA, 2004) for measuring depression, anxiety and stress. This is a 42-item, selfreport instrument measuring current (within the past week) symptoms of depression, anxiety and stress. Each of its three scales consists of 14 items that are answered by using a 0-3 scale, where $0=$ did not apply to me at all, and $3=$ applied to me very much or most of the time, making for a range of 0-42 for possible scores on each scale. Scores considered in the normal range are 0-9 for depression, 0-7 for anxiety and 0-14 for stress. Scores above these ranges indicate the degree of the problem, from mild to extreme. The Turkish version of this scale was constructed by Uncu, Bayram \& Bilgel (2006). The reliability coefficients (Cronbach's alpha) of the Turkish version of DASS-42 were found to be $0.89,0.82$ and 0.85 for depression, anxiety and stress, respectively (Bayram \& Bilgel 2008).

In addition to these two instruments, a separate questionnaire for socio-demographic data was filled out by the participants.

\subsection{Procedure}

All the questionnaires were distributed to the participants in closed envelopes and were later collected in the same manner. Participants were asked to fill out the questionnaires without any identifying marks. Distribution and collection of the questionnaires lasted about two weeks in each school, a process which took place outside of the exam period as much as possible. A total of 976 questionnaires (581 in Turkey, 395 in Germany) were distributed, and 846 questionnaires (505 in Turkey, 341 in Germany) were collected, making for a response ratio of $86.7 \%$.

\subsection{Data Analyses}

Data analyses were conducted by using the Statistical Package for the Social Sciences (SPSS version 17.1) program. A total of 84 questionnaires (63 in Turkey, 21 in Germany) had missing data and were excluded from the analyses. Besides descriptive statistics, 
correlation analysis, multivariate analyses of covariance (MANCOVA) and variance analysis were performed.

\section{Results}

Some demographic characteristics of the students are shown in Table 1 . Most of the participating students were female (64.3\%), and all students were between the ages of 14 and 18 years. Half of the total participants defined their families' economic situation as good.

Table 1

Some Demographic Characteristics of the Study Group

\begin{tabular}{|c|c|c|c|c|c|c|}
\hline \multirow[t]{2}{*}{ Demographic Characteristics } & \multicolumn{2}{|c|}{$\begin{array}{l}\text { Turkey } \\
(n=442)\end{array}$} & \multicolumn{2}{|c|}{$\begin{array}{l}\text { Germany } \\
(n=320)\end{array}$} & \multicolumn{2}{|c|}{$\begin{array}{c}\text { Total } \\
(\mathrm{N}=762)\end{array}$} \\
\hline & $\mathrm{n}$ & $\%$ & $\mathrm{n}$ & $\%$ & $\mathrm{n}$ & $\%$ \\
\hline \multicolumn{7}{|l|}{ Gender } \\
\hline Female & 286 & 64.7 & 204 & 63.8 & 490 & 63.4 \\
\hline Male & 156 & 35.3 & 116 & 36.3 & 272 & 35.7 \\
\hline \multicolumn{7}{|l|}{ Age } \\
\hline 14 & 83 & 18.8 & 32 & 10.0 & 115 & 15.1 \\
\hline 15 & 82 & 18.6 & 62 & 19.4 & 144 & 18.9 \\
\hline 16 & 106 & 24.0 & 62 & 19.4 & 168 & 22.0 \\
\hline 17 & 121 & 27.4 & 70 & 21.9 & 191 & 25.1 \\
\hline 18 & 50 & 11.3 & 94 & 29.4 & 144 & 18.9 \\
\hline \multicolumn{7}{|l|}{ Grade } \\
\hline 9. grade & 160 & 36.2 & 70 & 21.9 & 230 & 30.2 \\
\hline 10. grade & 75 & 17.0 & 78 & 24.4 & 153 & 20.1 \\
\hline 11. grade & 109 & 24.7 & 76 & 23.8 & 185 & 24.3 \\
\hline 12. grade & 98 & 22.2 & 96 & 30.0 & 194 & 25.5 \\
\hline \multicolumn{7}{|l|}{ Mother's education } \\
\hline Illiterate & 37 & 8.4 & 22 & 6.9 & 59 & 7.7 \\
\hline Primary & 247 & 55.9 & 102 & 31.9 & 349 & 45.8 \\
\hline Secondary & 73 & 16.5 & 82 & 25.6 & 155 & 20.3 \\
\hline High & 69 & 15.6 & 94 & 29.4 & 163 & 21.4 \\
\hline University+ & 16 & 3.6 & 20 & 6.3 & 36 & 4.7 \\
\hline \multicolumn{7}{|l|}{ Father's education } \\
\hline Illiterate & 11 & 2.5 & 12 & 3.8 & 23 & 3.0 \\
\hline Primary & 151 & 34.2 & 58 & 18.1 & 209 & 27.4 \\
\hline Secondary & 83 & 18.8 & 94 & 29.4 & 177 & 23.2 \\
\hline High & 105 & 23.8 & 116 & 36.3 & 221 & 29.0 \\
\hline University+ & 92 & 20.8 & 40 & 12.5 & 132 & 17.3 \\
\hline \multicolumn{7}{|l|}{ Economic situation } \\
\hline Good & 209 & 47.3 & 180 & 56.3 & 389 & 51.0 \\
\hline Moderate & 200 & 45.2 & 136 & 42.5 & 336 & 44.1 \\
\hline Bad & 33 & 7.5 & 4 & 1.3 & 37 & 4.9 \\
\hline
\end{tabular}

Table 2 shows the mean scores for the DASS-42 and MDAS. The mean ( $\mathrm{M} \pm \mathrm{SD}$ ) depression, anxiety and stress scores were, respectively, 10.63 $\pm 7.44,10.02 \pm 6.35$ and $16.40 \pm 7.43$, which indicated that there was mild depression, mild anxiety and mild stress among the study 
group. The total mean scores for every dimension of the MDAS and its subscales were found to be higher among the students in Turkey than those in Germany. 
Table 2

Means (M), Standard Deviations (SD) and Cronbach alpha values for the DASS-42 and MDAS

\begin{tabular}{lccccccc}
\hline \multirow{2}{*}{ Variables } & & \multicolumn{2}{c}{ Turkey $(\mathrm{n}=442)$} & \multicolumn{2}{c}{ Germany $(\mathrm{n}=320)$} & \multicolumn{2}{c}{ Total $(\mathrm{N}=762)$} \\
\cline { 3 - 8 } & Item & $\mathrm{M} \pm \mathrm{SD}$ & C.Alpha & $\mathrm{M} \pm \mathrm{SD}$ & $\mathrm{C}$.Alpha & $\mathrm{M} \pm \mathrm{SD}$ & $\mathrm{C}$. Alpha \\
\hline Depression & 14 & $10.99 \pm 7.54$ & .89 & $10.14 \pm 7.28$ & .88 & $10.63 \pm 7.44$ & .88 \\
Anxiety & 14 & $10.49 \pm 6.58$ & .84 & $9.36 \pm 5.95$ & .82 & $10.02 \pm 6.35$ & .83 \\
Stress & 14 & $16.95 \pm 7.25$ & .84 & $15.64 \pm 7.64$ & .87 & $16.40 \pm 7.43$ & .86 \\
\hline Anger symptoms & 14 & $35.35 \pm 11.62$ & .90 & $32.51 \pm 10.15$ & .86 & $34.15 \pm 11.10$ & .88 \\
\hline Anger eliciting situations (Total) & 41 & $162.54 \pm 24.43$ & .94 & $149.85 \pm 27.87$ & .95 & $157.21 \pm 26.64$ & .95 \\
$\quad$ Being belittled & 20 & $76.49 \pm 13.65$ & .91 & $69.52 \pm 14.54$ & .91 & $73.56 \pm 14.43$ & .92 \\
$\quad$ Being transgressed & 16 & $68.23 \pm 9.72$ & .88 & $64.14 \pm 12.37$ & .92 & $66.52 \pm 11.08$ & .90 \\
$\quad$ Being criticized & 5 & $17.81 \pm 4.04$ & .71 & $16.19 \pm 4.20$ & .72 & $17.13 \pm 4.18$ & .72 \\
\hline Anger related cognitions (Total) & 30 & $73.23 \pm 24.34$ & .94 & $67.54 \pm 21.36$ & .93 & $70.84 \pm 23.28$ & .94 \\
$\quad$ Regarding anger & 9 & $21.91 \pm 9.04$ & .90 & $20.42 \pm 8.02$ & .88 & $21.71 \pm 8.83$ & .90 \\
$\quad$ Regarding others & 9 & $22.17 \pm 7.62$ & .82 & $20.05 \pm 6.33$ & .77 & $21.28 \pm 7.18$ & .81 \\
$\quad$ Regarding him or herself & 7 & $17.38 \pm 5.81$ & .79 & $15.32 \pm 4.85$ & .71 & $16.51 \pm 5.51$ & .77 \\
$\quad$ Regarding the whole world & 5 & $11.28 \pm 5.15$ & .83 & $11.41 \pm 5.21$ & .85 & $11.33 \pm 5.17$ & .84 \\
\hline Behaviors related to anger & 26 & & & & & & \\
$\quad$ Aggressive behaviors & 12 & $31.48 \pm 10.44$ & .88 & $28.00 \pm 9.16$ & .85 & $30.02 \pm 10.06$ & .87 \\
$\quad$ Calm behaviors & 10 & $28.66 \pm 8.07$ & .82 & $27.94 \pm 7.59$ & .80 & $28.36 \pm 7.87$ & .81 \\
$\quad$ Anxious behaviors & 4 & $12.94 \pm 3.76$ & .73 & $12.29 \pm 3.61$ & .72 & $12.67 \pm 3.71$ & .73 \\
\hline Interpersonal anger & 47 & & & & & & \\
$\quad$ Being revengeful & 24 & $66.08 \pm 22.28$ & .95 & $63.22 \pm 21.10$ & .94 & $64.88 \pm 21.81$ & .95 \\
Passive-aggressive reactions & 10 & $33.04 \pm 8.97$ & .86 & $31.16 \pm 8.81$ & .85 & $32.25 \pm 8.94$ & .86 \\
Inwards directed reactions & 10 & $30.19 \pm 7.91$ & .80 & $28.84 \pm 7.91$ & .81 & $29.63 \pm 7.93$ & .81 \\
Being indifferent & 3 & $7.95 \pm 3.51$ & .79 & $8.14 \pm 3.14$ & .74 & $8.03 \pm 3.06$ & .77 \\
\hline
\end{tabular}


Table 3 shows the correlations between depression, anxiety and stress and different dimensions of anger. We found strong and positive correlations between dimensions of anger and depression, anxiety and stress. The only exception to this correlation was among Turkish students in Germany with regard to the being indifferent subscale of the interpersonal anger dimension.

Table 3

Correlations between the MDAS and DASS-42

\begin{tabular}{lcccccc}
\hline & \multicolumn{2}{c}{ Turkey $(\mathrm{n}=442)$} & \multicolumn{2}{c}{ Germany $(\mathrm{n}=320)$} \\
& $\mathrm{D}$ & $\mathrm{A}$ & $\mathrm{S}$ & $\mathrm{D}$ & $\mathrm{A}$ & $\mathrm{S}$ \\
\hline Anger symptoms & $.570^{* *}$ & $.627^{* *}$ & $.660^{* *}$ & $.656^{* *}$ & $.700^{* *}$ & $.681^{* *}$ \\
\hline Anger eliciting situations & & & & & & \\
\hline Being belittled & $.188^{* *}$ & $.152^{* *}$ & $.267^{* *}$ & $.250^{* *}$ & $.200^{* *}$ & $.335^{* *}$ \\
Being transgressed & $.133^{* *}$ & $.107^{*}$ & $.275^{* *}$ & $.221^{* *}$ & $.225^{* *}$ & $.387^{* *}$ \\
Being criticized & $.272^{* *}$ & $.220^{* *}$ & $.348^{* *}$ & $.262^{* *}$ & $.256^{* *}$ & $.335^{* *}$ \\
\hline Anger related cognitions & & & & & & \\
\hline Regarding anger & $.539^{* *}$ & $.515^{* *}$ & $.640^{* *}$ & $.584^{* *}$ & $.526^{* *}$ & $.679^{* *}$ \\
Regarding others & $.599^{* *}$ & $.559^{* *}$ & $.579^{* *}$ & $.509^{* *}$ & $.503^{* *}$ & $.536^{* *}$ \\
Regarding him or herself & $.588^{* *}$ & $.539^{* *}$ & $.529^{* *}$ & $.503^{* *}$ & $.520^{* *}$ & $.447^{* *}$ \\
Regarding the whole world & $.633^{* *}$ & $.508^{* *}$ & $.577^{* *}$ & $.625^{* *}$ & $.584^{* *}$ & $.538^{* *}$ \\
\hline Behaviors related to anger & & & & & & \\
\hline Aggressive behaviors & $.459^{* *}$ & $.372^{* *}$ & $.526^{* *}$ & $.374^{* *}$ & $.331^{* *}$ & $.457^{* *}$ \\
Calm behaviors & $.160^{* *}$ & $.225^{* *}$ & $.116^{*}$ & $.194^{* *}$ & $.248^{* *}$ & $.266^{* *}$ \\
Anxious behaviors & $.418^{* *}$ & $.373^{* *}$ & $.444^{* *}$ & $.453^{* *}$ & $.402^{* *}$ & $.474^{* *}$ \\
\hline Interpersonal anger & & & & & & \\
\hline Being revengeful & $.420^{* *}$ & $.318^{* *}$ & $.487^{* *}$ & $.309^{* *}$ & $.298^{* *}$ & $.406^{* *}$ \\
Passive-aggressive reactions & $.360^{* *}$ & $.286^{* *}$ & $.464^{* *}$ & $.309^{* *}$ & $.292^{* *}$ & $.368^{* *}$ \\
Inwards directed reactions & $.402^{* *}$ & $.387^{* *}$ & $.427^{* *}$ & $.358^{* *}$ & $.399^{* *}$ & $.352^{* *}$ \\
Being indifferent & $.150^{* *}$ & $.188^{* *}$ & $.168^{* *}$ & .019 & .000 & $.012^{*}$ \\
\hline
\end{tabular}

** Correlation is significant at the 0.01 level

$D=$ Depression; $A=$ Anxiety; $S=$ Stress

The distribution of the study group ( $\mathrm{N}=762$ ) according to the mean scores of anger related behaviors and interpersonal anger reactions is shown in Figures 1 and 2 .

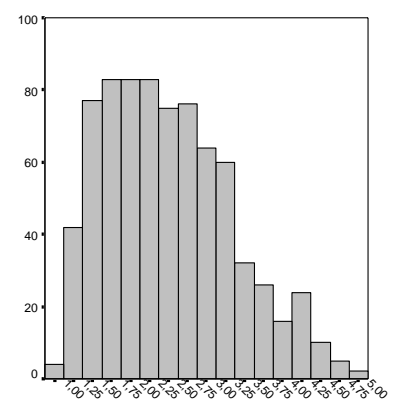

Aggressive reactions

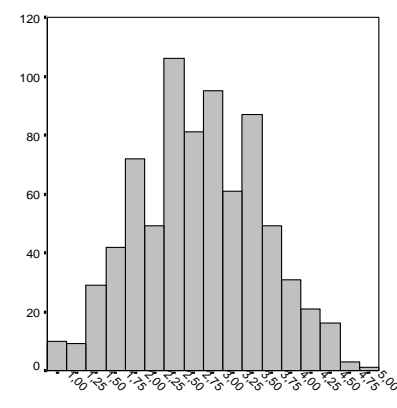

Calm reactions

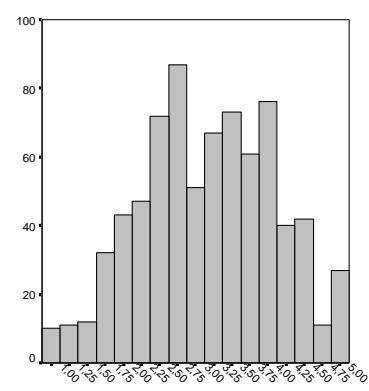

Anxious reactions 
Figure 1. Distribution of the study group according to anger-related behaviors

For the aggressive reactions, the histogram is skewed to the left which means that many of the students in the study group show little or no aggressive reactions. The histogram of the calm reactions shows a normal distribution and the histogram of anxious reactions is a little bit right skewed.

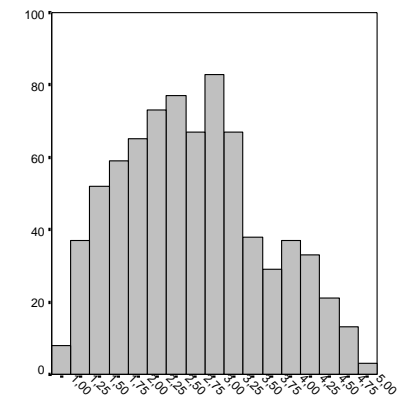

Being revengeful

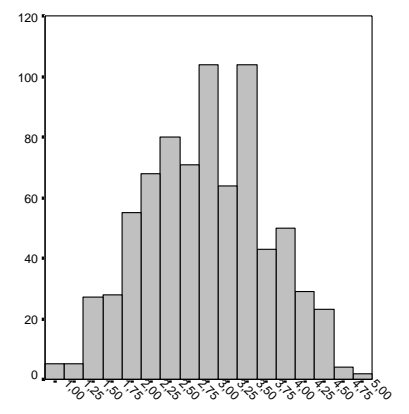

Inwards directed reactions

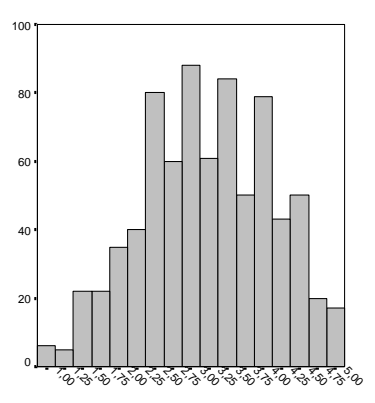

Passive-aggressive reactions

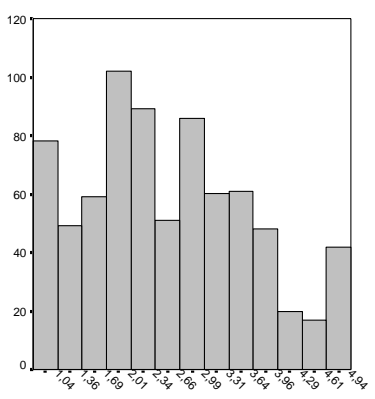

Being indifferent

Figure 2. Distribution of the study group according to interpersonal anger reactions

Among interpersonal anger reactions, the distributions of being revengeful and being indifferent are skewed to the left, whereas the inwards directed reactions histogram shows a normal distribution and the histogram of passive-aggressive reactions is skewed to the right. These results suggest that while students in the study group are not revengeful or indifferent in terms of their interpersonal anger reactions, they are passive-aggressive.

As it is shown in Table 4. general linear modeling with two-way multivariate analyses of covariance (MANCOVA) was used to determine the main effects of country and gender on depression, anxiety, stress and all subscale scores of anger. Age was used as a control for confounding variables that might influence the response of the dependent variables. Results are presented as means and standard deviations and, for individual outcomes, as partial eta squared. The results of MANCOVA demonstrated a significant main effect for country [Wilks's lambda=0.843, $F(740)=7.67 ; \mathrm{df}=18 ; \mathrm{p}<0.001, \eta 2=0.16$ ]. The main effect for gender was also significant [Wilks's lambda $=0.809, F(740)=9.68 ; d f=18 ; p<0.001, \eta 2=0.19$ ], and gender's interaction with country was significant as well [Wilks's lambda $=0.957, F(740)=1.83$; $\mathrm{df}=18 ; \mathrm{p}<0.019, \mathrm{\eta} 2=0.04]$. As can be seen in Table 4, students in Turkey had higher mean scores for anxiety and stress than those in Germany. Scores for anger symptoms were also higher for students in Turkey. For the anger eliciting situations dimension of the MDAS, 
students from Turkey received higher scores than those from Germany. This suggests that students in Turkey are more prone to anger eliciting situations such as being belittled, transgressed against and criticized. For the anger-related cognition dimension of the MDAS, the students in Turkey again had higher scores than those in Germany in terms of angerrelated cognition regarding anger, regarding him or herself and regarding others, although the scores for anger-related cognition regarding the whole world showed no difference between students in Turkey and Germany. For the behaviors related to anger dimension of the MDAS, aggressive and anxious behaviors were found to be higher among students in Turkey, whereas calm behaviors showed no difference between the two groups. For the interpersonal anger dimension of the MDAS, passive-aggressive and inwards directed reactions were found to be higher among students in Turkey than those in Germany, while reactions of being revengeful and being indifferent showed no difference. There were significant main effects for country and gender after controlling for age. For all anger eliciting situations (being belittled, being transgressed against and being criticized), female students scored higher than male students $(p<0.001)$. Meanwhile, male students scored significantly higher than female students in terms of aggressive behaviors $(p<0.001)$. Groups differed significantly $(p<0.001)$ from each other on the post hoc comparisons. 
Table 4

Two-way multivariate analyses of covariance (MANCOVA) for country and gender

\begin{tabular}{|c|c|c|c|c|c|c|c|c|c|c|}
\hline & \multicolumn{2}{|c|}{ Turkey } & \multicolumn{2}{|c|}{ Germany } & \multicolumn{2}{|c|}{ Country } & \multicolumn{2}{|c|}{ Gender } & \multicolumn{2}{|c|}{ Country*Gender } \\
\hline & $\begin{array}{c}\text { Female } \\
(n=286) \\
M \pm S D\end{array}$ & $\begin{array}{c}\text { Male } \\
(n=156) \\
M \pm S D\end{array}$ & $\begin{array}{c}\text { Female } \\
(n=204) \\
M \pm S D\end{array}$ & $\begin{array}{c}\text { Male } \\
(n=116) \\
M \pm S D\end{array}$ & $F$ & $\mathrm{p}$ & $F$ & $\mathrm{p}$ & $F$ & $\mathrm{p}$ \\
\hline Depression & $11.26 \pm 7.45$ & $10.50 \pm 7.72$ & $10.16 \pm 7.12$ & $10.10 \pm 7.59$ & 3.76 & .053 & .32 & .568 & 1.69 & .193 \\
\hline Anxiety & $10.70 \pm 6.58$ & $10.13 \pm 6.60$ & $9.37 \pm 6.10$ & $9.33 \pm 5.70$ & 8.13 & .004 & .23 & .627 & 1.57 & .211 \\
\hline Stress & $17.38 \pm 7.12$ & $16.16 \pm 7.43$ & $15.72 \pm 7.82$ & $15.52 \pm 7.30$ & 7.22 & .007 & 1.24 & .264 & 2.58 & .108 \\
\hline Anger symptoms & $2.56 \pm .83$ & $2.45 \pm .83$ & $2.31 \pm .77$ & $2.35 \pm .63$ & 13.58 & .000 & .21 & .649 & 4.00 & .046 \\
\hline \multicolumn{11}{|l|}{$\begin{array}{l}\text { Anger eliciting } \\
\text { situations }\end{array}$} \\
\hline Being belittled & $3.98 \pm .61$ & $3.55 \pm .72$ & $3.51 \pm .70$ & $3.41 \pm .77$ & 39.28 & .000 & 24.63 & .000 & 13.58 & .000 \\
\hline Being transgressed & $4.38 \pm .52$ & $4.06 \pm .70$ & $4.10 \pm .74$ & $3.85 \pm .80$ & 32.01 & .000 & 29.93 & .000 & 2.74 & .098 \\
\hline Being criticized & $3.69 \pm .79$ & $3.32 \pm .80$ & $3.26 \pm .89$ & $3.19 \pm .75$ & 23.86 & .000 & 12.16 & .001 & 7.60 & .006 \\
\hline \multicolumn{11}{|l|}{$\begin{array}{l}\text { Anger related } \\
\text { cognitions }\end{array}$} \\
\hline Regarding anger & $2.51 \pm 1.06$ & $2.45 \pm .99$ & $2.19 \pm .93$ & $2.51 \pm .78$ & 4.57 & .033 & 3.63 & .057 & 8.65 & .003 \\
\hline Regarding others & $2.48 \pm .84$ & $2.43 \pm .85$ & $2.18 \pm .71$ & $2.31 \pm .68$ & 15.75 & .000 & .57 & .448 & 3.86 & .050 \\
\hline $\begin{array}{l}\text { Regarding him or } \\
\text { herself }\end{array}$ & $2.48 \pm .82$ & $2.50 \pm .84$ & $2.14 \pm .70$ & $2.28 \pm .66$ & 26.86 & .000 & 2.16 & .142 & 2.23 & .135 \\
\hline $\begin{array}{l}\text { Regarding the whole } \\
\text { world }\end{array}$ & $2.28 \pm 1.04$ & $2.21 \pm 1.02$ & $2.23 \pm 1.10$ & $2.37 \pm .92$ & .07 & .785 & .19 & .660 & 3.19 & .074 \\
\hline \multicolumn{11}{|l|}{$\begin{array}{l}\text { Behaviors related to } \\
\text { anger }\end{array}$} \\
\hline Aggressive behaviors & $2.57 \pm .87$ & $2.72 \pm .86$ & $2.12 \pm .70$ & $2.71 \pm .71$ & 18.46 & .000 & 39.22 & .000 & 17.54 & .000 \\
\hline Calm behaviors & $2.88 \pm .80$ & $2.83 \pm .83$ & $2.78 \pm .77$ & $2.81 \pm .74$ & 2.74 & .098 & .000 & .995 & 1.88 & .170 \\
\hline Anxious behaviors & $3.32 \pm .96$ & $3.09 \pm .88$ & $3.08 \pm .94$ & $3.07 \pm .83$ & 6.37 & .012 & 2.37 & .124 & 5.36 & .021 \\
\hline \multicolumn{11}{|l|}{ Interpersonal anger } \\
\hline Being revengeful & $2.75 \pm .94$ & $2.77 \pm .92$ & $2.48 \pm .88$ & $2.91 \pm .81$ & 1.40 & .237 & 11.37 & .001 & 10.90 & .001 \\
\hline
\end{tabular}


Passive-aggressive

\section{reactions}

Inwards directed

reactions

\begin{tabular}{cccccccccc}
$3.38 \pm .88$ & $3.16 \pm .92$ & $3.11 \pm .90$ & $3.12 \pm .85$ & 8.70 & .003 & 2.25 & .134 & 6.28 & .012 \\
$3.07 \pm .79$ & $2.93 \pm .79$ & $2.89 \pm .77$ & $2.87 \pm .82$ & 7.23 & .007 & 1.38 & .240 & 3.61 & .058 \\
$2.63 \pm 1.16$ & $2.68 \pm 1.19$ & $2.56 \pm 1.03$ & $2.98 \pm 1.03$ & .89 & .345 & 8.11 & .005 & 6.34 & .012 \\
\hline
\end{tabular}


Table 5 shows the mean DASS-42 and MDAS scores according to grade. We found significant differences between grades in terms of anxiety, anger symptoms, anger-related situations, anger-related cognition regarding the whole world, calm and anxious behaviors related to anger, and passive-aggressive and inwards directed reactions. The DASS-42 and MDAS scores tended to increase as the grade increased. 
Table 5

Mean DASS-42 and MDAS scores according to grade

\begin{tabular}{|c|c|c|c|c|c|c|c|c|}
\hline \multicolumn{9}{|c|}{ Grade } \\
\hline Variables & $\begin{array}{l}\text { 9. grade } \\
(n=230)\end{array}$ & $\begin{array}{c}\text { 10. grade } \\
(n=153)\end{array}$ & $\begin{array}{l}\text { 11. grade } \\
(n=185)\end{array}$ & $\begin{array}{c}\text { 12. grade } \\
(n=194)\end{array}$ & $\begin{array}{c}\text { Total } \\
(\mathrm{N}=762)\end{array}$ & $\mathrm{F}$ & $\mathrm{p}$ & Post Hoc \\
\hline Depression & $9.75 \pm 7.47$ & $10.86 \pm 7.40$ & $11.02 \pm 6.63$ & $11.13 \pm 8.11$ & $10.63 \pm 7.44$ & 1.588 & .191 & - \\
\hline Anxiety & $9.30 \pm 6.26$ & $9.50 \pm 5.12$ & $10.37 \pm 6.48$ & $10.94 \pm 7.07$ & $10.02 \pm 6.35$ & 2.911 & .034 & $12>9$ \\
\hline Stress & $15.53 \pm 7.49$ & $15.86 \pm 6.82$ & $17.38 \pm 7.54$ & $16.93 \pm 7.62$ & $16.40 \pm 7.43$ & 2.749 & .052 & - \\
\hline Anger symptoms & $2.28 \pm .76$ & $2.49 \pm .75$ & $2.51 \pm .79$ & $2.52 \pm .84$ & $2.44 \pm .79$ & 4.601 & .003 & $9<11=12$ \\
\hline \multicolumn{9}{|l|}{ Anger related situations } \\
\hline Being belittled & $3.66 \pm .82$ & $3.64 \pm .77$ & $3.76 \pm .62$ & $3.65 \pm .64$ & $3.68 \pm .72$ & 1.128 & .337 & - \\
\hline Being transgressed & $4.03 \pm .80$ & $4.10 \pm .79$ & $4.32 \pm .54$ & $4.20 \pm .55$ & $4.16 \pm .69$ & 6.927 & .000 & $9<11=12 ; 10<11$ \\
\hline Being criticized & $3.32 \pm .89$ & $3.65 \pm .85$ & $3.44 \pm .85$ & $3.36 \pm .70$ & $3.43 \pm .84$ & 5.531 & .001 & $10>9=12$ \\
\hline \multicolumn{9}{|l|}{ Anger related cognitions } \\
\hline Regarding anger & $2.31 \pm .95$ & $2.49 \pm .85$ & $2.51 \pm 1.07$ & $2.38 \pm 1.01$ & $2.41 \pm .98$ & 1.903 & .128 & - \\
\hline Regarding others & $2.26 \pm .81$ & $2.46 \pm .79$ & $2.42 \pm .80$ & $2.35 \pm .78$ & $2.36 \pm .80$ & 2.290 & .077 & - \\
\hline Regarding him or herself & $2.27 \pm .75$ & $2.35 \pm .76$ & $2.46 \pm .79$ & $2.37 \pm .84$ & $2.36 \pm .79$ & 2.041 & .107 & - \\
\hline Regarding the whole world & $2.13 \pm .98$ & $2.36 \pm 1.02$ & $2.42 \pm 1.11$ & $2.21 \pm 1.02$ & $2.27 \pm 1.03$ & 3.170 & .024 & $11>9$ \\
\hline \multicolumn{9}{|l|}{ Anger related behaviors } \\
\hline Aggressive behaviors & $2.45 \pm .84$ & $2.47 \pm .79$ & $2.57 \pm .84$ & $2.52 \pm .86$ & $2.50 \pm .84$ & .856 & .464 & - \\
\hline Calm behaviors & $2.75 \pm .78$ & $2.63 \pm .76$ & $2.95 \pm .76$ & $2.99 \pm .80$ & $2.84 \pm .79$ & 8.566 & .000 & $11=12>9=10$ \\
\hline Anxious behaviors & $3.02 \pm .92$ & $3.08 \pm .95$ & $3.27 \pm .91$ & $3.31 \pm .90$ & $3.17 \pm .93$ & 4.657 & .003 & $11=12>9$ \\
\hline \multicolumn{9}{|l|}{ Interpersonal anger } \\
\hline Being revengeful & $2.62 \pm .93$ & $2.78 \pm .89$ & $2.72 \pm .84$ & $2.73 \pm .96$ & $2.70 \pm .91$ & .975 & .404 & - \\
\hline Passive-aggressive reactions & $3.02 \pm .94$ & $3.19 \pm .92$ & $3.36 \pm .83$ & $3.36 \pm .83$ & $3.22 \pm .89$ & 7.213 & .000 & $11=12>9$ \\
\hline Inwards directed reactions & $2.83 \pm .83$ & $2.87 \pm .79$ & $3.07 \pm .75$ & $3.10 \pm .75$ & $2.96 \pm .79$ & 6.022 & .000 & $9<11=12 ; 10<12$ \\
\hline Being indifferent & $2.57 \pm 1.10$ & $2.67 \pm 1.12$ & $2.73 \pm 1.13$ & $2.75 \pm 1.12$ & $2.68 \pm 1.12$ & 1.066 & .363 & - \\
\hline
\end{tabular}




\section{Discussion}

In this study we found some gender differences in terms of the different dimensions of the MDAS. Being belittled, transgressed against and criticized were more important among female students than among male students. In his study regarding school anger, Boman (2003) found that "spreading a rumor" and "having a best friend make fun of one's hair or clothing" affected males and females very differently, with these items being more relevant to the female experience of anger.

Studies involving adolescents and children have generally reported no differences between boys and girls with regard to the experience of anger (Fabes \& Eisenberg, 1992; Boman, 2003). However, these studies and others have reported significant gender differences in the expression of anger, reporting that boys were more likely than girls to express their anger physically (Maccoby \& Jacklin, 1980; Crick, 1997; Cox, Stabb \& Hulgus, 2000). Similar results were obtained from our study. In contrast to these results, in their study of male and female adolescents, Swaffer \& Epps (1999) found no significant differences in either the experience or the expression of anger. In our study, female students were more likely than male students to express their anger by showing anxious behaviors, which reflects the fact that female students tended to use more internalized means for coping with anger than males - namely, suppression and control. This finding was similar to those of Cox, Stabb, \& Hulgus (2000).

Taking account of the results of the entire group, regardless of gender differentiation, we observed certain differences in terms of anger, depression, anxiety and stress between the students in Germany and the students in Turkey.

We found no significant difference in the depression level of the students. In both of the countries, students had mild depression. The anxiety and stress levels of students in Turkey, however, were higher than those in Germany. Anger symptoms were also more frequent among students in Turkey. Cognitions of anger related to the whole world were similar for students in Turkey and Germany, but cognitions of anger related to anger, related to others and related to him or herself were higher among students in Turkey. Anger expression as aggressive and anxious behaviors was higher among students in Turkey, as were passive-aggressive reactions and inwards directed reactions.

With regards to the two countries, we found differences among male and female students in terms of anger-related situations and anger expression. Among students in Turkey, being belittled, transgressed against and criticized were more important anger-related situations for females than for males, whereas among students in Germany only being transgressed against was more important for female students. Some studies in Turkey have shown that females were more affected by anger eliciting situations but that they did not express their anger as aggressive behaviors (Balkaya \& Şahin, 2003; Batıgün-Durak \& Şahin-Hisli, 2003; Şahin-Hisli \& Batıgün-Durak, 2009). This study showed that in Turkey, anxious behaviors as an expression of anger were seen more among female students, whereas in Germany, aggressive behaviors were more frequent among male students. Our findings regarding interpersonal anger revealed a difference between male and female students in Turkey, where passive-aggressive reactions were seen more frequently among females. On the other hand, for students in Germany, being revengeful and indifferent were mostly found among male students when interpersonal anger was taken into account. These differences and their causes merit further study. 
In terms of depression, anxiety and stress, we found no differences among male and female students in either Turkey or Germany.

We found that the anxiety level and anger symptoms of students increased along with the increase in grade. As can be seen in Table 6, being transgressed against and being criticized became more important as an anger eliciting situation in the higher grades. A similar trend was obtained for anger-related cognitions regarding the whole world. Expression of anger as calm and anxious reactions also seems to increase with grade. Similar findings were obtained in Balkaya \& Şahin's (2003) study, which confirmed that the expression of anger as a calm reaction may reflect personal maturity and could be accepted as a sign of positive coping with anger with increasing age. Similar tendencies were found for interpersonal anger in terms of passiveaggressive and inwards directed reactions.

\section{Conclusion and Recommendation}

There are few studies in Turkey regarding anger in high school students, rendering it impossible to make proper comparisons. Our study suggests a need for anger management programs as well as effective initiatives for reducing depression, anxiety and stress in high schools.

Some key points of this study could be summarized as follows:

1. Anger is a common problem among high school students.

2. Scores of anger symptoms were found to be higher among students in Turkey.

3. Being belittled, transgressed against and criticized are important anger eliciting situations for high school students.

4. Male students showed aggressive reactions as anger-related behavior more than female students.

5. Female students showed anxious reactions as anger-related behavior more than male students.

6. Revengeful reactions were more common among male students.

7. Among students in Germany, aggressive reactions were more common among males than females, whereas in Turkey no gender differences were found.

8. Among students in Turkey, anxious reactions were more common among females, whereas in Germany no gender differences were found.

9. Revengeful reactions were higher among male students in Germany, whereas in Turkey no gender differences were found.

10. Passive-aggressive reactions were higher among female students in Turkey, whereas in Germany no gender differences were found.

11. All of the scores for the subscales of the MDAS increased as the students' grade increased.

\section{Limitations}

The cross-sectional design and self-reported structure of this study are major limitations. The study's results are limited to the study group and cannot be generalized.

\section{References}

American Psychological Association [APA]. (2007). Controlling anger-before it controls you. Retrieved March 22, 2007, from http://www.apa.org/topics/controlanger.html 
Balkaya, F., \& Şahin-Hisli, N. (2003). Çok boyutlu öfke ölçeği [Multidimensional anger scale]. Türk Psikiyatri Dergisi, 14(3), 192-202. Retrieved June 18, 2010, from http://www.turkpsikiyatri.com/default.aspx?modul=ingilizceOzet\&gFPrkMakale=437

Batıgün-Durak, A.,\& Şahin-Hisli, N. (2003). Öfke, dürtüsellik ve problem çözme becerilerindeki yetersizlik gençlik intiharlarının habercisi olabilir mi? [Can anger, impulsivity, and perceiving oneself as an inefficient problem solver be a forerunner of adolescent suicide]. Türk Psikoloji Dergisi, 18(51), 53-57. Retrieved April 10, 2012, from http://www.turkpsikolojidergisi.com/PDF/TPD/51/37-57.pdf

Batıgün-Durak, A.,\& Utku, Ç. (2006). Bir grup gençte yeme tutumu ve öfke arasındaki ilişkinin incelenmesi. [A study among a group of adolescents and young adults on the relationship between eating attitudes and anger]. Türk Psikoloji Dergisi, 21(57),79-82. Retrieved April,10 2012, from http://www.turkpsikolojidergisi.com/PDF/TPD/57/65-82.pdf

Bayram, N.,\& Bilgel, N. (2008). The prevalence and socio-demographic correlations of depression, anxiety and stress among a group of university students. Social Psychiatry and Psychiatric Epidemiology, 43(8),667-672. Retrieved April 25, 2008, from http://link.springer.com/article/10.1007/s00127-008-0345-x/fulltext.html

Boman, P.(2003). Gender differences in school anger. International Education Journal, 4(2),7177. Retrieved April 25, 2012, from http://www.iejcomparative.org/data/volumes/v4n2.pdf

Ceylan, A., Özen, Ş., \& Palancı, Y. (2003). Lise son sınıf öğrencilerinde anksiyete-depresyon düzeyleri ve zararlı alışkanlıklar: Mardin çalışması. [Anxiety and depression levels among 12 grade high school students: Mardin study ] Anadolu Psikiyatri Dergisi, 4(3), 144-150. Retrieved June 18 2012, from http://psikiyatridizini.net/viewarticle.php?article id=334

Çivitçi, N. (2007). Çok boyutlu öfke ölçeğinin Türkçeye uyarlanması: Geçerlik ve güvenirlik çalışmaları [The adaptation of multidimensional school anger inventory into Turkish: validity and reliability studies] Pamukkale Üniversitesi Eğitim Fakültesi Dergisi, 22(2), 99109. Retrieved April 10, from http://pauegitimdergi.pau.edu.tr/Makaleler/817375630 Nazmiye\%20\%c3\%87ivit\%c3\%a7i 2.pdf

Cox, D.L., Stabb, S.D., \& Hulgus, J.F. (2000). Anger and depression in girls and boys: A study of gender differences. Psychology of Women Quarterly, 24(1), 110-112. Retrieved March 20, 2012, from DOI:10.1111/j.1471-6402.2000.tb01027.x

Crick, N.R. (1997). Engagement in gender normative versus nonnormative forms of agression: Links to social-psychological adjustment. Developmental Psychology, 33(4), 610-617. Retrieved March 25, 2012, from http://psycnet.apa.org/journals/dev/33/4/610/

Eskin, M., Ertekin, K., Harlak, H., \& Dereboy, Ç. (2008). Prevalence of and factors related to depression in high school students. Türk Psikiyatri Dergisi, 19(4), 382-389.

Retrieved June 18, 2012, from http://www.turkpsikiyatri.com/default.aspx?modul=ingilizceOzet\&gFPrkMakale=660

Fabes, R.A., \& Eisenberg, N. (1992). Young children's coping with interpersonal anger. Child Development, 63(1), 116-128. Retrieved March 25, 2012, from http://www.jstor.org/stable/1130906

Golden, B. (2003). Healthy anger: How to help children and teens manage their anger. New York: Oxford University Press. 
Goodwin, R.D. (2006). Association between coping with anger and feelings of depression among youths. American Journal of Public Health, 96(4), 664-669. Retrieved March 29, 2012, from http://ajph.aphapublications.org/doi/pdf/10.2105/AJPH.2004.049742

Kassinove, H., \& Sukhodolsky, D.G. (1995). Anger disorders: basic science and practice issues. In H. Kassinove (Ed.), Anger Disorders: Definition, Diagnosis and Treatment (p.7). Washington:Taylor \& Francis.

Kitamura, T., \& Hasui, C. (2006). Anger feelings and anger expression as a mediator of the effects of witnessing family violence on anxiety and depression in Japanese adolescents. Journal of Interpersonal Violence, 21(7),843-855. Retrieved March 29, 2012, from http://jiv.sagepub.com/content/21/7/843

Koh, K.B., Kim, D.K., Kim, S.Y.,\& Park, J.K. (2005). The relation between anger expression, depression, and somatic symptoms in depressive disorders and somatoform disorders.

Journal of Clinical Psychiatry, 66(4), 485-491. Retrieved March 29, 2012, from http://www.psychiatrist.com/abstracts/abstracts.asp?abstract=200504/040511.htm

Köksal, F., \& Gençdoğan, B. (2007). Depresif olanlarla olmayanların suçluluk, utanç ve öfke tarzlarının incelenmesi. [Types of shame quilt and anger among depressed and nondepressed]. Atatürk Üniversitesi Sosyal Bilimler Enstitüsü Dergisi, 9(1),163-175. Retrieved April 10, 2012, from http://e-dergi.atauni.edu.tr/index.php/SBED/article/view/399/392

Lewis M.(1993). The development of anger and rage. In R.A. Glick, S.P. Roofe (Eds), Rage power and aggression: The role of affect in motivation, development, and adaptation (pp.148-168). New Haven: Yale University Press.

Maccoby, E.E., \& Jacklin,C.N. (1980). Sex differences in aggression: A rejoinder and reprise. Child Development, 51(4), 964-980. Retrieved March 12 2011, from http://www.jstor.org/stable/1129535

Novaco, R. (1975). Anger control: The development and evaluation of an experimental treatment. Lexington, MA: Heath.

Orpinas, P.K., Basen-Engquist, K., Grunbaum, J.A.,\& Parcel, G.S.(1995). The co-morbidity of violence-related behaviors with health-risk behaviors in a population of high school students. Journal of Adolescent Health, 16(3), 216-225. Retrieved May 10, 2012, from http://www.sciencedirect.com/science/article/pii/1054139X94000670\#

Parker-Hall, S. (2008). Anger, Rage and Relationship: An Empathic Approach to Anger Management. London: Routledge.

PFA- Psychology Foundation of Australia. Depression Anxiety and Stress Scales (DASS). Retrieved March 25, 2004, from http://www2.psy.unsw.edu.au/Groups/Dass/

Sperberg, E.D., \& Stabb, S.D.(1998). Depression in women as related to anger and mutuality in relationships, Psychology of Women Quarterly, 22(2), 223-238.

Retrieved March 17, 2012, from http://onlinelibrary.wiley.com/doi/10.1111/j.14716402.1998.tb00152.x/pdf

Spielberger, C. (1999). State-Trait Anger Expression Inventory-2 Professional Manual. Lutz, FL: Psychological Assessment Resources, Inc.

Şahin-Hisli, N., \& Batıgün-Durak, A. (2009). Testing the probability of a model to predict suicide risk in high school and university students. Türk Psikiyatri Dergisi, 20(1):28-36. Retrieved 
June

18 ,

2012

from

http://www.turkpsikiyatri.com/default.aspx?modul=ingilizceOzet\&gFPrkMakale $=678$

Swaffer, T., \& Epps, K. (1999). The psychometric assessment of anger in male and female adolescents resident at a secure youth treatment centre. Journal of Adolescence, 22(3), 419422. Retrieved May 12, 2011, from http://www.sciencedirect.com/science/article/pii/S0140197199902336

Thomas, S.P., \& Atakan, S. (1993). Trait anger, anger expression, stress, and health status of American and Turkish midlife women. Health Care Women International, 14(2),129-143.

Uncu, Y., Bayram, N.,\& Bilgel, N. (2006). Job related affective well-being among primary health care physicians. European Journal of Public Health, 17(5), 514-519. Retrieved March 25, 2007, from http://eurpub.oxfordjournals.org/content/17/5/514.full.pdf+html

Verschuur, M.J., Eurelings-Bontekoe, E.H.,\& Spinhoven, P. (2004). Associations among homesickness, anger, anxiety and depression, Psychological Reports, 94, 1155-1170. 